\title{
THE IMPACT OF MODIFICATION TECHNIQUES ON THE RHEOLOGICAL PROPERTIES OF DYSPHAGIA FOODS AND LIQUIDS
}

\author{
Short Title: Impact of Modification on Rheology of Dysphagia Foods \\ Marilize de Villiers ${ }^{1}$, Ben Hanson², Legini Moodley ${ }^{1}$, Mershen Pillay ${ }^{1}$ \\ 1. School of Health Sciences, Discipline of Speech-Language Pathology, University of KwaZulu-Natal, \\ Durban, South Africa \\ 2. UCL Mechanical Engineering, University College London, London, United Kingdom
}

\section{Abstract}

Modifying food and textures of food has been done for decades within the food science and technology field. More recently, modifying texture of foods has been used to manage swallowing disabilities (dysphagia). Swallowing disabilities are often associated with dehydration and malnutrition, thus nutritional intervention has formed part of serving texture-modified diets. The question remains whether these modification techniques are viable for individuals with swallowing disabilities living in majority world countries. This study used two modification methods on a widely used Specialized Nutritious Food (SNF) to determine whether it may be modified and used in dysphagia management. The techniques had to be ergonomic and economically appropriate for individuals with swallowing disabilities living in majority world countries. The International Dysphagia Diet Standardization Initiative's (IDDSI) standards were used to determine whether the texturally modified SNF is safe for swallowing. Rheological measurements were performed to determine apparent viscosity and structure recovery of each sample. The effects of two modification techniques, aeration and particle separation, on the rheological properties of the SNF were also measured and analyzed. It was determined that both milk and water could be used with this SNF to create a dysphagia diet, but only under certain conditions. The overall results indicated that heating the samples increased the apparent viscosity and exacerbated lumping. Room temperature samples had less lumps and could be classified to the desired levels of the IDDSI (Level 2 and Level 4). Using a whisk to aerate the samples reduced lumps significantly and using a sieve to separate particles of liquid samples eliminated lumps. 


\section{Practical Application}

This study provides new data on how texture modification techniques and the IDDSI framework could be adapted to individuals living in majority world countries. By using modification techniques that are ergonomic and economically viable and a SNF with longevity, this study could be useful in guiding future training of nursing staff and caregivers of individuals living in poverty or resource-constrained communities. This study also adds to the data on rheological properties of dysphagia foods, although this study did not make use of commercial thickeners generally used in the modification of diets.

Keyword: Dysphagia, swallowing disabilities, texture modification, texture-modified diets, rheology, viscosity, dysphagia food 


\section{Introduction}

Food texture modification has been done for years by various fields. It commenced in the field of food science and technology where food products with different tastes, textures, and nutritional values are created using ingredients such as thickeners, additives, and preservatives to thicken, increase the shelf-life, sweeten, and improve nutrition. They use techniques such as pureeing, dehydration, rehydration, and ultrasound to create fruit purees, seasoning or vegetable powders, and dried fruits (Awad, Moharram, Shaltout, Asker, \& Youssef, 2012; Dolatowski, Stadnik, \& Stasiak, 2007; Haghi, 2010; Jeantet, Croguennec, Schuck, \& Brulé, 2016; Mcclements, 1995; Roday, 2012). Food science is focused on food production on an industrial scale and focus on safety and nutrition. More recently, the molecular gastronomy field, a cooking approach that combines food science (scientific processes and ingredients) and domestic cooking (Barham, Skibsted, Bredie, \& Risbo, 2010), emerged. Molecular gastronomy chefs use similar ingredients, sodium alginate and calcium chloride, and techniques, dehydration, as food scientists to create palatable and interesting meals. Molecular gastronomy focuses more on conceivable methods used in restaurants where smaller amounts of food are created (Barham et al., 2010). Finally, the speechlanguage pathology field started modifying food textures in the management of swallowing disabilities where individuals require food and liquids that are easier to swallow (Ney, Weiss, Kind, \& Robbins, 2009). The texture modification techniques used by food scientists and technologists and in molecular gastronomy are often difficult to use in domestic cooking, especially by those with disabilities, such as swallowing disabilities, and those living in majority world countries. Because of affordability or physical access, most people do not have access to the ingredients, such as sodium alginate, and technology, such as dehydration instruments, that food scientists and technologists use.

As the need for texture-modified diets for individuals with swallowing disabilities increased, the food science industry collaborated with the health care industry to create commercial products to help modify individuals' diets. The most widely used commercial products are starch-based or gum-based thickeners (Lotong, Chun, Chambers, \& Garcia, 2003; Seo \& Yoo, 2013). These thickeners must be used correctly by health workers, caregivers, family members, and speech-language 
pathologists to create the correct consistency for individuals. Many are not modified correctly despite multiple classification or categorization systems describing different consistencies and providing guidelines for the modification of food and liquids.

The International Dysphagia Diets Standardization Initiative (IDDSI) recently developed descriptions and guidelines for dysphagia diets that are considered safe based on years of literature and research. This framework is suitable for all ages, all care settings and all cultures (Cichero et al., 2016; Lam, Stanschus, Zaman, \& Cichero, 2017). Pre-thickened or pre-prepared dysphagia foods also exist to reduce mixing or preparation errors, primarily in the form of supplementary food prescribed by dieticians, such as sip-feeds or nutritionally dense puddings (Brook, 2015; McFarlane, Miles, Atwal, \& Parmar, 2014). These products have been designed because swallowing disabilities often lead to malnutrition (Cichero et al., 2013) and individuals often require supplementation. There are other food products designed by food scientists and technologists that are not specifically for individuals with swallowing disabilities but that could be used as dysphagia foods, such as infant fruit purees, yogurt, smooth jams, cream cheese, and mousse pudding (McFarlane et al., 2014). Commercial bulk texture-modified foods have been developed (Landry, 2009), however, these foods do not necessarily improve the nutritional status of individuals with dysphagia even though it improves intake (Keller et al., 2012a). Keller et al. (2012a) introduced a reformed commercial product that was produced using methods that reduced dilution of nutrients and conserved the taste.

Swallowing disabilities are highly prevalent among the elderly, with about 27-68\% affected (Singh \& Hamdy, 2006; Sura, Madhavan, Carnaby, \& Crary, 2012), and with the growing population of elderly people, food industries are feeling more pressured to produce appropriate texture-modified meals for them (Su et al., 2018). The problem, however, remains that most of these commercially available products cannot be accessed by individuals with swallowing disabilities living in majority world countries or in resource constrained communities, such as villages far from the city. Many of these products are only available in selected shops and pharmacies and costs more than the average person living in an informal settlement can afford. One example is a thickening powder that is only available at selected pharmacies in South Africa and costs around ZAR 190.00 (ca.US\$13.00) for a $300 \mathrm{~g}$ tin, which might last a patient one 
week; the average person living in an informal settlement spends around ZAR 70.00 (ca. US\$ 4.50) on food per week (Statistics South Africa, 2015).

There are many techniques to modify food that individuals can easily use at home. These include breaking down the texture by chopping, dicing, mincing, blending, or grinding, thus altering the rheological properties, such as viscosity, cohesiveness adhesiveness, and texture. In some cases, food thickeners, such as flour, corn flour, or commercial food thickeners, are added to reduce fluid loss during the altering of the food. In other cases, liquid is added to food that naturally contains less fluids, such as bread or meat (Keller et al., 2012b). Adding liquid to modify food may reduce overall nutritional value, and larger portions are needed to maintain the same nutritional intake (Vivanti, Campbell, Suter, Hannan-Jones, \& Hulcombe, 2009). Many of these techniques require resources (e.g. electricity) and appliances (e.g. microwave ovens, stove-tops, and blenders) and people in majority world countries are often unable to afford these resources and appliances to use the modification techniques.

In South Africa, for example, the poorest $66 \%$ of households receive about $21 \%$ of all income (Visagie, 2013). More than half of South Africans live in poverty (Cole, 2015). It is therefore important to determine how these techniques can be adapted for majority world countries and communities where ergonomic (efficiency and practicality) and economic factors need to be considered. These factors include the cost of the techniques and ingredients, the ease of access to the ingredients and equipment required, and the time it takes to use the modification techniques. Many people from majority world countries live far from town and do not have food stores close to them. They often do not have money to get to town where these stores are, thus the equipment and ingredients required should not be too expensive. These communities are often unable to shop regularly because of income constraints (Oldewage-Theron, Dicks, \& Napier, 2006), thus these techniques should not include ingredients that will not stay preserved for less than a month. The Tackling Hunger through Research and Innovation for Vulnerable Environments (THRIVE) project (Pillay \& Kathard, 2018) is currently attempting to reduce food insecurity by providing people with Specialized Nutritious Foods (SNFs) that stay preserved for months. SNF is a term coined by the World Food Program to label fortified and nutritionally dense food (World Food Program, 2017). The equipment required should also not be too big and heavy as many of these individuals access shops by taking public transport or walking and 
would be unable to carry or transport big and heavy equipment. Finally, the techniques should be easy and quick to follow as many of these individuals live in big multigenerational households.

Many individuals with swallowing disabilities also have other disabilities such as paralysis or paresis due to stroke (Blackwell \& Littlejohns, 2010). As poor nutrition and unhealthy lifestyles often run parallel living in majority world countries, the prevalence of non-communicable diseases, such as strokes, are often high (Mayosi et al., 2009; Padarath, King, \& English, 2016). Almost $50 \%$ of individuals admitted to three private rehabilitation centers in South Africa following stroke presented with swallowing disabilities (Blackwell \& Littlejohns, 2010), and over $60 \%$ of adults in nursing homes presents with swallowing disabilities (Sura et al., 2012), which may be even higher in the public sector or low-income communities. These statistics highlight the importance of adapting texture modification techniques to be ergonomic and economically appropriate for individuals living in majority world countries and resource-constrained communities. This study sought to describe how the IDDSI can be applied to a low-tomiddle-income country such as South Africa using viable ergonomic and economical techniques and an indigenous SNF with a prolonged shelf-life.

The rheological properties of a food or drink are altered, when the consistency of this food or drink is modified. However, modification techniques and thickening agents are not always used appropriately, and individuals' diets often do not have the correct rheological properties for safe swallowing. Cichero (2016) reviewed the characteristics of what she labeled as the "ideal swallow-safe bolus" and describes how any type of food are degraded by mastication and saliva to a swallow-safe bolus. A swallow-safe bolus is soft, cohesive, and smooth in texture, easily initiates the swallow, and moves swiftly through the pharynx (Hoebler et al., 1998; Loret et al., 2011; Motoi, Morgenstern, Duncan, Wilson, \& Balita, 2013 in Cichero, 2013). By modifying a patient's food or drink, we try to produce a bolus that is already safe for swallowing as many individuals do not have the ability to chew a bolus to the ideal texture. When modifying food and liquids, it is important to be aware of how the modification techniques influence the rheological properties and thus the safety of the food and liquids.

The core aim of this study was to determine the effects of different preparation methods and conditions on the bolus rheology in terms of shear stress, viscosity, and 
structure recovery, and safety according to the IDDSI standards. The following variables were tested: Two different modification techniques, aeration and separation; fat and protein content; and temperature. The last two variables were tested with both modification methods. The results of this study served to guide the development of a caregiver training program for the management of swallowing disabilities in lowincome communities.

\section{Materials and Methods}

\subsection{Preparation for this Study}

Before this study could be executed, preliminary data on most frequently prescribed dysphagia diets, the SNF, and the modification techniques had to be collected and analyzed to select appropriate materials and methods.

Modification techniques had to be selected based on ergonomic and economical appropriateness within a low-income community. Criteria for the modification techniques was developed based on literature and statistics in South Africa. The techniques had to be low technology; not require electricity; not require equipment or ingredients that are difficult or expensive to acquire; be effortless; and be efficient. The average household in an urban informal settlement (low-income community) spends about ZAR 30.00 (ca. US\$2.00) per day on food. Households in urban informal settings and traditional areas consist of an average of three to four members (Statistics South Africa, 2015). This means there is ZAR 7.50-10.00 (ca. US\$ 0.50-0.70) for food per person per day. The ingredients selected had to have a prolonged shelf-life as many individuals only shop once or twice per month (Oldewage-Theron et al., 2006). The ingredients selected should also contain sufficient nutrition to ensure that individuals feel full and have enough energy to carry them through the day (in cases where individuals only eat one main meal per day).

Two modification techniques were selected based on the selection criteria: Aeration achieved by foaming, and particle separation achieved by straining with a sieve. Foaming, a term used by the molecular gastronomy field, refers to the process of whipping air into a mixture (Liu, 2014; This, 2002, 2005, 2006) or aerating a mixture. A hand whisk was used to foam the samples. Straining was done by first stirring the mixture with a fork and then straining it with a sieve into a cup, and thus separating 
the liquid from the solid particles (Detyna \& Bieniek, 2008). These two modification techniques were tested as the first objective (Obj.1). As the packaging of the SNF indicates that either milk or water may be used, the second objective (Obj.2) was to determine the effect of the fat and protein content of full cream milk on the apparent viscosity and safety of the samples for individuals with swallowing disabilities. Different thermal properties were tested as the third objective (Obj.3) to determine the effect of heat on the rheology and safety of the bolus. According to the literature, heat causes starch to swell and thicken (Hoover \& Manuel, 1996), and it is thus important to ensure that the correct amount of liquid is added so as to not serve meals that are too thick for individuals with swallowing disabilities.

Figure 2.1 provides a visual representation of the first three objectives. The last objective was to determine the structural behavior of the prepared samples to determine the effect time and delayed shear stress on the rheological properties of the SNF because meals for individuals with swallowing disabilities are often prepared long before it is served.

Figure 1: Visual Representation of Objectives 1-3

[Figure 1 Here]

The selected SNF is described as a pre-cooked porridge powder and, according to the packaging, the main ingredients are whole grain maize and soybeans. It was selected based on the following criteria:

1. It is widely available, according to the creators (via electronic communication), at selected pharmacies nationwide, non-governmental organizations, and humanitarian organizations, and some hospitals situated in urban informal settlements use this SNF in their feeding schemes.

2. It is used by the project THRIVE (Pillay \& Kathard, 2018), of which this study forms part.

3. It is affordable in terms of costs, shelf-life, and the number of meals that can be made from one packet. One meal of this SNF will cost ZAR 2.99 (ca. US\$0.20) and one packet makes ten meals.

4. According to the creators (via electronic correspondence) it contains vitamins and minerals that are easily absorbed by the body and one portion provides an 
individual with the required micro-nutrients for the day (See Appendix A for the nutritional information of the SNF).

The techniques and ingredients combined would cost between ZAR 2.99 (ca. US\$ 0.20 ) and ZAR 4.20 (ca. US\$ 0.30) per meal, assuming the individuals already have the required equipment, such as a hand whisk. The equipment needed will cost between ZAR 76.95 (ca. US\$ 5.30) and ZAR 172.83 (ca. US\$ 12.00) once-off. Households in urban informal settlements spend around ZAR 178.38 (ca. US\$12.35) on household equipment and furnishings per month (Statistics South Africa, 2015).

This study aimed to determine the effect of modification techniques and conditions on the safety of the bolus according to the IDDSI standards. The samples were classified according to the IDDSI to determine safety after modification. Two levels of the IDDSI framework were selected based on the results of an online survey in the form of a selfadministered close-ended questionnaire. Convenience and purposive sampling were used to select participants by distributing the online survey to 821 speech-language pathologists in South Africa registered with the South African Speech, Language and Hearing Association. It was designed to determine the current most frequently prescribed dysphagia diets, how it is labelled by speech-language pathologists, and how these labels match the IDDSI Levels. In total 27 participants completed the survey. A sample of 5-25 is adequate for the interpretive paradigm (Babbie \& Mouton, 2001 in Andrews \& Pillay, 2017). The online survey revealed that Level 2 (mildly thick liquids) and Level 4 (puree food) were prescribed most frequently to individuals with swallowing disabilities in South Africa.

According to the IDDSI descriptions, Level 2 liquids flow quickly from a spoon but slower than thin liquids, and it takes some effort to drink through a standard bore straw. The IDDSI states that Level 4 food shows very slow movement under gravity, cannot be drunk from a cup, and cannot be sucked through a straw. It does not require chewing, has no lumps, and is not sticky (Cichero et al., 2016).

\subsection{Preparing the Samples}

Based on the preparation phase of this study, nine samples were prepared in total. The preparation of the samples is described below. 


\subsubsection{Sample 1: Baseline}

The SNF was prepared using the standard instructions on the packaging: It was prepared by mixing $50 \mathrm{~g}$ of the SNF powder with $150 \mathrm{ml}$ of water with a spoon. A pretest was conducted with the IDDSI testing methods (see next section) to determine the IDDSI Level of the SNF before it was modified. The IDDSI fork drip test revealed that the baseline SNF was too runny to be classified as Level 4 and might be classified as Level 3 (moderately thick liquids). The baseline SNF contained lumps and could not truly be classified on the IDDSI framework as each level on the IDDSI has to be homogeneous in texture. The IDDSI syringe flow test could not be performed due to lumps, and thus a true level for the SNF could not be determined. These results provided some guidance as to how the SNF should be modified. The aim was to create both Level 2 liquids and Level 4 food, and the researcher determined that either less or more fluid had to be added to the SNF powder to create thinner and thicker consistencies than the baseline. A larger volume of milk was used than water as the fat and protein content of milk tend to produce thicker mixtures (Crittenden, Trussell, Hand, Howe, \& Tchobanoglous, 2012; Ting, Liu, Tian-Li, \& Lu-Hua, 2016).

\subsubsection{Samples 2-5: Foaming (Aeration)}

The aim of this technique was to create Level 4 food. Two of these samples were prepared at room temperature by mixing $50 \mathrm{~g}$ of SNF powder with $100 \mathrm{ml}$ of room temperature milk and $80 \mathrm{ml}$ of room temperature water, respectively. The remaining two samples were prepared by adding $100 \mathrm{ml}$ of heated milk and $80 \mathrm{ml}$ of heated water, respectively, to $50 \mathrm{~g}$ of SNF powder.

\subsubsection{Samples 6-9: Straining (Particle Separation)}

The aim of this technique was to create Level 2 liquids. These were also prepared using different thermal properties. Each sample was prepared using $200 \mathrm{ml}$ of either room temperature or heated milk and $170 \mathrm{ml}$ of either room temperature or heated water, respectively, to $50 \mathrm{~g}$ of SNF powder. The IDDSI syringe flow test was used to determine whether samples tested were on Level 2 of the IDDSI. Appendix B explains each preparation and modification technique in more detail.

\subsection{International Dysphagia Diets Standardization Initiative Classification}

Each of the nine samples was tested using the IDDSI testing methods to determine whether each sample can be classified on the IDDSI framework and whether these 
tests could qualitatively measure the boluses effectively. The Separation samples were tested using the syringe flow test: This test is performed by filling a $10 \mathrm{ml}$ syringe up to $10 \mathrm{ml}$ with the liquid to be tested. Using a stopwatch, the liquid is dripped through the nozzle of the syringe for 10 seconds. The amount of liquid left in the syringe after 10 seconds gives an indication of the thickness of the liquid. Level 2 liquids flow through the syringe leaving $4-8 \mathrm{ml}$ in the syringe (Cichero et al., 2016).

The Aeration samples were tested by means of the fork pressure test and the spoon tilt test. The fork pressure test requires the sample to be pressed with a fork until the thumbnail blanches. The spoon tilt test is performed by scooping the sample onto the spoon and tilting the spoon to observe the behavior of the sample in terms of movement. Level 4 food is cohesive enough to hold its shape on a spoon and the whole spoonful plops from a spoon when it is tilted or turned sideways (Cichero et al., 2016). See Appendix $C$ for detailed descriptions of the syringe flow test, fork pressure test, and the spoon tilt test.

\subsection{Rheological Experiments}

The rheological experiments were completed in a controlled laboratory with the aid of a qualified pharmacist and PhD candidate at the University of KwaZulu-Natal. All experiments were performed on an MCR 302 Rheometer 214 (Anton Paar, GmbH, Graz, Austria) using a parallel plate (PP50-SN42714) with a plate diameter of $49.969 \mathrm{~mm}\left(0.995^{\circ}\right.$, shear rate $\left.0.01-100 \mathrm{~s}^{-1}\right)$. Data analysis was completed using RheoCompass software (version 1.15) (Anton Paar).

The following measurements were executed to determine whether the different modification techniques, liquid used and thermal effects applied to the samples would create boluses that are safe for individuals with swallowing disabilities, and to determine what effect these modifications would have on the apparent viscosity and structure of the boluses.

Flow/viscosity curves and flow behavior were obtained by rotational tests with a controlled shear rate. Shear rate $(\dot{\gamma})$ needed to be controlled as the aim was to determine apparent viscosity $(\eta)$ and shear stress $(\tau)$ measurements at a desired shear rate $\left(0-100 \mathrm{~s}^{-1}\right)$ (Mezger, 2006). Controlled shear rate was used to duplicate previous dysphagia studies (Garcia \& Chambers, 2008; Garcia, Chambers, Matta, 
International, \& Clark, 2005; Garcia, Chambers, Clark, Helverson, \& Matta, 2010; Garin et al., 2014; Howard, Nissenson, Meeks, \& Rosario, 2018; Kim \& Joo, 2015; Leonard, White, McKenzie, \& Belafsky, 2014). According to Mezger (2006), controlled shear rate (CSR) tests are used when certain process conditions need to be simulated, as with the process of swallowing. The shear rate within the oral cavity, pharynx and esophagus of a person with normal swallowing abilities may range between $50 \mathrm{~s}^{-1}$ and $100 \mathrm{~s}^{-1}$, depending on what is consumed. There are pools and vortexes ("eddies") with slower and faster flow. Research on the shear rate within the abnormal oral cavity, pharynx, and esophagus is limited, so $50 \mathrm{~s}^{-1}$ is believed to be representative as an average (Cichero \& Lam, 2014). Shear rates within the pharynx may exceed $100 \mathrm{~s}^{-1}$ (Salinas-Vázquez et al., 2014) but this study is focused on thickened liquids and pureed food that are designed for people with abnormal or weaker oral cavities and pharyngeal constrictor muscles, food and liquids that are meant to have slower shear rates. Although there appears to be no data on the average shear rates within abnormal oral cavities of individuals with swallowing disabilities, it has been suggested that shear rates may be less than $50 \mathrm{~s}^{-1}$ (Cichero \& Lam, 2014). Room temperature and serving temperature were used for the samples in accordance with prior dysphagia studies reporting on viscosity (Garcia \& Chambers, 2008; Garcia et al., 2010; Garin et al., 2014; Kim \& Joo, 2015; Leonard et al., 2014; Zargaraan, Omaraee, et al., 2013).The mean of three replicates for all apparent viscosity and shear stress measurements are reported.

Three interval thixotropy tests (3 ITT) in oscillating-rotation-oscillating intervals were used to measure structure breakdown and recovery: Oscillating (measuring viscosity at a shear rate of $1 \mathrm{~s}^{-1}$ for 120 seconds); rotation (measuring viscosity at a shear rate of $100 \mathrm{~s}^{-1}$ for 120 seconds); oscillating (measuring viscosity at a shear rate of $1 \mathrm{~s}^{-1}$ for 300 seconds). This test was performed to determine how the structure of the SNF reacts to applied shear stress and how it recovers after the shear stress is removed. The mean of two replicates of each sample were used to report the thixotropy findings.

\subsection{Reliability and Validity}

Reliability or consistency of the data collection instrument and results (Hernon \& Schwartz, 2009) was ensured by using standardized tests and measurements designed to measure rheological properties (internal reliability), by measuring 2-3 
replicates of each sample, and by involving a second researcher in the rheological measurements (external reliability).

During the rheological measurements, only one independent variable was altered per measurement to ensure internal validity, thus that the effect on the dependent variable (apparent viscosity) was due to the manipulation if the independent variable (Hernon \& Schwartz, 2009; McLeod, 2013). To ensure external validity, or generalizability and applicability of results (McLeod, 2013), measurements were performed under replicable conditions by creating and using standard instructions for sample preparation and standardized rheological measurements; and a locally available SNF was used ensuring that the results are applicable to South Africa.

\section{Results}

The rheology results indicated that the apparent viscosity at a shear rate of $50 \mathrm{~s}^{-1}$ of the baseline sample was 2.4Pa.s. Structure recovery was not tested as this sample was only used as baseline for apparent viscosity measurements of the other samples. The IDDSI testing methods were used to determine whether the different samples are safe to qualify as a dysphagia diet according to the IDDSI framework, thus homogenous in texture. It was also completed to determine whether the samples could be classified on the levels identified during the online survey of this study. These testing methods revealed that the baseline sample, which was prepared using the instructions on the packaging, might have been on Level 3 (moderately thick) if it did not contain lumps.

\subsection{Aeration}

The IDDSI testing methods revealed that all the room temperature aeration samples, with and without fat and protein content could be classified as Level 4 (Puree food). These samples' apparent viscosities were 11.9-14.8Pa.s (at a shear rate of $50 \mathrm{~s}^{-1}$ ). The heated aeration samples, with and without fat and protein content, were too thick and heterogeneous in texture to be classified according to the IDDSI framework. The apparent viscosities of the heated aeration samples measured 26.7-39.7Pa.s at a shear rate of $50 \mathrm{~s}^{-1}$. Table 2.1 provides detailed descriptions of the results of the IDDSI measurements and Table 2.2 contains detailed results of the rheological measurements. 


\subsection{Separation}

The room temperature separation samples, both with and without fat and protein content could be classified as Level 2 of the IDDSI. The apparent viscosities of these samples were $0.82-0.84 \mathrm{~Pa} \cdot \mathrm{s}$. The heated separation samples, with and without fat and protein content, were thicker than the desired level; although they could still be classified according to the standards of the IDDSI. Table 2.1 provides a detailed description of the IDDSI measuring results. The apparent viscosity measurements of the heated separation samples were $0.58-1.7 \mathrm{~Pa} \cdot \mathrm{s}$. This is quite a large range of apparent viscosities that could be classified as Level 3, much like the National Dysphagia Diet classification's description of honey thick liquids, which described viscosity ranges of $0.35-1.75 \mathrm{~Pa} \cdot \mathrm{s}$ (American Dietetic Association, \& National Dysphagia Diet Task Force, 2002). Fat and protein content did not have a significant effect on the outcomes in terms of IDDSI classification. Table 2.2 has more information on the rheology results.

\section{Table 1: IDDSI Measurements and Results}

[Table 1 Here]

Although it was apparent that the samples thicken over time when it is not stirred or disturbed (when shear stress is not being applied), thixotropy results revealed that none of the samples recovered to $50 \%$ of the original structural strength after 300 seconds (5 minutes). Table 2.2 contains detailed results of the rheological measurements. All the samples did, however, show a slight upward trend by the end of the 5 minutes which indicates that the samples' structures were still recovering, thus thickening when no shear stress is applied.

Table 2: Rheological Measurements and Results

[Table 2 Here]

Figures 2.2 and 2.3 show the flow behavior of the four separation samples and the four aeration samples, respectively. Both sets of samples displayed pseudoplastic or shear thinning behavior and all the samples had a non-Newtonian flow. When shear rate increases, apparent viscosity decreases.

Figure 2: Flow Behavior of Level 2 Separation Samples (mean of three replicates)

[Figure 2 Here] 
Figure 3: Flow Behavior of Level 4 Aeration Samples (mean of three replicates)

[Figure 3 Here]

During this study it was clear that the L4 Aeration samples' apparent viscosities increased over time when shear stress is not applied. Figure 2.4 gives an example of how the room temperature L4 Aeration samples thickened over time. There was a waiting period of 10 minutes between each sample (while the tests run).

Figure 4: Difference in Apparent Viscosities over Time (L4 Aeration)

[Figure 4 Here]

\section{Discussion}

This study set out to create a swallow-safe bolus for individuals with swallowing disabilities by determining whether a local SNF could be modified as a dysphagia diet, and what effect different modification techniques and conditions would have on bolus rheology and safety in terms of swallowing, by classifying the bolus as safe, or not, according to IDDSI standards. We were also interested in the structure of the samples in terms of what happens to apparent viscosity over time and the structure breakdown and recovery of the samples after shear stress has been applied. We were interested in determining whether time would influence the safety of the samples for individuals with swallowing disabilities. The results of this study would serve as a guide in developing a dysphagia diet training program for caregivers.

The aeration or foaming technique was successful in creating swallow-safe boluses at room temperature, with or without fat and protein content, but unsuccessful when heat was added. The room temperature L4 Aeration samples could successfully be classified as Level 4 food according to the IDDSI spoon tilt test. Subjectively, adding heat to the $L 4$ Aeration samples not only made them too thick, but also caused the samples to be less homogeneous in texture. Both heated L4 Aeration samples, with and without fat and protein content, was too thick and lumpy to be classified according to the IDDSI classification framework. These results were unexpected as the apparent viscosities of both water and milk usually decrease with higher temperatures (Crittenden et al., 2012; Kumbár \& Nedomová, 2015). This could be because the SNF contains maize, which tends to thicken and gelify when heated (Gunaratne \& Hoover, 2002; Hoover \& Manuel, 1996). 
The particle separation method, whether room temperature or heated, with or without fat and protein content, was successful in creating swallow-safe boluses that is homogeneous in texture (Cichero, 2016). Although the heated samples were thicker, they could still be classified according to the IDDSI standards of dysphagia diets as they were smooth and did not contain lumps (Cichero et al., 2016). According to the IDDSI syringe flow test, the room temperature $L 2$ Separation samples were both classified as Level 2 liquids, with and without fat and protein content. Adding heat to the L2 Separation samples increased apparent viscosity, except for L2 Heated Milk Separation. This sample was also classified as Level 2 according to the IDDSI syringe flow test. The heated $L 2$ Separation sample prepared with water was classified as Level 3 as measured with the IDDSI syringe flow test. Adding the same volume of heated water to the same amount of SNF powder, as with the room temperature water and SNF powder, caused the sample to be thicker than desired. This increase in viscosity with temperature could be attributed to the composition of the SNF, which contains starch. Starch is increasingly cross-linked with temperature, e.g. during conventional cooking, which is believed to be what happened to the starch during the preparation of the heated samples (Gunaratne \& Hoover, 2002; Sun, Nan, Dai, \& Xiong, 2015).

An interesting finding was that $L 2$ Heated Milk Separation sample did not have a higher apparent viscosity than the L2 RT Milk Separation sample, as was the case with all the other heated samples. According to Zargaraan, et al (2013), even the slightest change in temperature (by 1 or 2 degrees) can have a significant effect on apparent viscosity. Temperatures of the heated samples were attempted to be kept stable, and the liquids were each heated for the same duration and measured with a thermometer. Upon further investigation, it was noted that the L2 Heated Milk Separation sample was tested at $55^{\circ} \mathrm{C}$, whereas the other heated samples' temperatures were between $48^{\circ} \mathrm{C}$ and $50^{\circ} \mathrm{C}$. This slight difference in temperatures could have affected the differences in apparent viscosities. When the $L 2$ Heated Milk Separation sample was prepared and measured again during the thixotropy tests, it had a higher apparent viscosity than the L2 RT Milk Separation sample, which made more sense when compared to the behavior of the other heated samples.

It is unclear why these results were so inconsistent but may be due to researcher error or lumps. All the Separation samples made a significant number of lumps, prior to 
separation of particles with a sieve. It is possible that when the L2 Heated Milk Separation sample was mixed the first time, it was not stirred thoroughly to dissolve most of the lumps. Therefore, it is so important to follow instructions carefully and have a low-technology method of testing meals before serving it to individuals. The IDDSI, therefore, developed low-technology testing methods. Although the L2 Heated Milk Separation sample was measured using the syringe flow test and was classified as Level 2 liquids, the researcher duplicated the syringe flow test the second time the $L 2$ Heated Milk Separation sample was prepared for the thixotropy tests. This time it was classified as Level 3: moderately thick liquids.

When comparing the rheology measurements at the chosen shear rate of $50 \mathrm{~s}^{-1}$ and the IDDSI testing results, it is apparent that these two types of measurements are not equivalent, and no direct mapping can be attempted. However, from the results viscosities of 1.5-2.5Pa.s generally could be compared to Level 3 (moderately thick) when measured with the IDDSI testing methods. This outcome is only valid for these SNF products and would not apply to other types of dysphagia management products such as gum-thickened liquids, for example. Viscosities below 1.0Pa.s seemed to be comparable to Level 2 liquids when measured with the IDDSI testing methods.

The SNF used tends to form lumps, which was exacerbated by adding heat. During this study it was discovered that adding the milk or water slowly while stirring and then mixing or foaming vigorously for at least two minutes reduced lumping significantly. When more liquid is added to the SNF (as in the L2 Separation samples), the aeration technique did not eradicate lumps and a sieve had to be used to separate the solid particles (lumps) from the liquid. With the L4 Aeration samples, where lower volumes of milk or water was added, lumping was less apparent and foaming or aerating the mixture robustly for at least two minutes with a whisk almost completely dissolved the lumps. Neither of the heated L4 Aeration samples had the correct Level 4 consistency and would be ruled out as a meal option when creating a training program for the management of swallowing disabilities.

The L4 Aeration samples showed an increase in apparent viscosity over time (Figure 3). With each replicate of the $L 4$ Aeration samples, there was a waiting period of 10 minutes before the next replicate could be tested because of the time it takes for the rheological tests to run. Subjectively, it was apparent that the heated L4 Aeration samples thickened so much more rapidly than the room temperature $L 4$ Aeration 
samples that the researcher could not do replicate tests with the same sample. New samples had to be prepared for each replicate of the heated L4 Aeration samples. During the IDDSI measurements the $L 4$ Aeration samples were left for 45 minutes testing at every 15 minutes. With the IDDSI's subjective testing methods it appeared that the room temperature $L 4$ Aeration samples only became too thick to be classified after 30 minutes.

Not all the $L 2$ Separation samples revealed this behavior. The room temperature $L 2$ Separation samples did not have much difference in apparent viscosity as time passed. In some cases, it showed a slight increase in apparent viscosity, and in other cases, it showed a slight decrease in apparent viscosity, but there was no statistically significant difference. The heated $L 2$ Separation samples revealed the same thickening tendencies as with all the puree samples. This may be attributed to the temperatures of the samples decreasing with time (cooling). All the heated samples ( $L 2$ Separation and L4 Aerated) practically gelled as it cooled. It would not be regarded as swallow-safe, indicating that time would cause a bolus to become unsafe for a patient with swallowing disabilities. During the measurements of the L2 Separation samples, using the IDDSI testing methods, it was noted that the room temperature $L 2$ Separation samples start to thicken after 30 minutes, and that it is possible for it to become too thick for individuals to swallow safely after 30 minutes.

From the three interval thixotropy tests it appears that all the samples show thixotropic behavior. There was a decrease in the structural strength with applied shear stress, which is a characteristic of pseudoplastic materials like these samples. The samples did not recover to their original structure during testing. It must, however, be noted that the recovery interval was only run for 5 minutes. The samples might have recovered $100 \%$ if enough time were allowed, as results displayed an ongoing upward trend by the end of the 5 minutes. This may indicate that the structures of all the samples will continue to recover.

These results are extremely important when working with individuals with swallowing disabilities, especially within a low-income, resource-restricted community. There are many factors to consider when preparing food and liquids for individuals with swallowing disabilities, such as: 
- The time from preparation to serving of food-the SNF's apparent viscosity increases over time and many individuals are only served their food 30 minutes after preparation, especially in hospitals and institutions;

- Preparation or stirring practices-stirring with a fork (dispersion) and beating with a whisk (aeration) would have different effects on the apparent viscosity and texture of food;

- Structure recovery of the SNF-as seen in the results, this SNF may thicken over time, but stirring (or aerating) the SNF vigorously would decrease apparent viscosity and it would take some time to return to the original thickness; and

- The importance of testing food and liquids for the correct consistency, such as the IDDSI testing methods.

There are therefore many factors affecting the repeatability of these results; identifying these factors was one of this study's aims. As with most experiments, close guidelines need to be followed to obtain the desired results. This study served to identify and describe the guidelines that should be followed when creating these meals on Level 2 and Level 4 of the IDDSI framework.

\section{Conclusion}

During the preparation of the baseline sample, it was discovered that this specific SNF forms lumps if it is merely mixed according to the instructions on the packaging. This study provided techniques in which this SNF may be prepared to eliminate the lumps. Data from this study on the effects of modification techniques on bolus rheology, suggests that room temperature aerated samples of the SNF mixed with either water or milk, created swallow-safe boluses. These were also classified on the Level 4 of the IDDSI framework as per the online survey. This study also revealed that either room temperature or heated separation samples prepared with either water or milk, created swallow-safe boluses. Generally, heating this SNF produced too thick and heterogeneous textures for some individuals to eat, especially if it was meant to create a puree diet, and was not separated through a sieve. According to the online survey, most individuals are prescribed Level 2 liquids, and adding the same volume of room temperature water as heated water does not create liquids on the same levels of the IDDSI framework, although both samples were still swallow-safe. The heated samples seemed to be more susceptible to apparent viscosity changes than the room 
temperature samples. The room temperature L4 Aeration samples do however demonstrate more rapid thickening than the room temperature $L 2$ Separation samples, but as the thixotropy results revealed, this can be remedied by stirring the sample again before serving it to a patient. The techniques that were successful in creating swallow-safe meals can be described as ergonomic and economically appropriate for majority world countries; they are cheap, simple, quick, and do not require electricity.

This study focused on room temperature and heated samples of food and thickened liquids at typical serving temperature. The SNF used can be eaten at room temperature or heated. In many hospitals the time between preparation and serving takes long resulting in food being served after it has already cooled. As discussed, heat may alter the consistency of food or liquids as it enters the oral cavity and mixes with warm saliva. Future studies could attempt to include an analysis of similar samples and the effect body temperature and saliva may have on the viscosity and consistency of the samples, though these effects vary widely between individuals. This study used controlled shear rates, which is an idealized test in comparison to the oral cavity and pharynx in which the bolus will experience a range of shear rates at any time. Future studies could also include individuals' opinions in terms of ease of swallowing, taste, and texture because it has been proven that it is important to serve individuals meals that they find appealing.

\section{Ethical Statements}

The authors declare no conflict of interest for this study. There were no human or animal testing during this study, and informed consent was obtained from participants who answered the online survey.

\section{Acknowledgments}

This study forms part of a larger body of research, Tackling Hunger via Research and Innovation for Vulnerable Environments (THRIVE), whose member was the academic supervisor of this study. We would also like to thank the Discipline of Pharmaceutics of the University of KwaZulu-Natal for letting us use their laboratories for the rheological experiments as well as Mr Calvin A. Omolo and Dr Ayman A. Waddad from this department who helped us with conducting the rheological experiments. 


\section{References}

American Dietetic Association, \& National Dysphagia Diet Task Force. (2002). The national dysphagia diet (NDD) : standardization for optimal care (First; J. Clayton, Ed.). Chicago: Diana Faulhaber.

Andrews, M., \& Pillay, M. (2017). Poor consistency in evaluating South African adults with neurogenic dysphagia. South African Journal of Communication Disorders, 64(1), 1-14. https://doi.org/10.4102/sajcd.v64i1.158

Awad, T. S., Moharram, H. A., Shaltout, O. E., Asker, D., \& Youssef, M. M. (2012). Applications of ultrasound in analysis, processing and quality control of food: A review. FRIN, 48(2), 410-427. https://doi.org/10.1016/j.foodres.2012.05.004

Barham, P., Skibsted, L. H., Bredie, W. L. P., \& Risbo, J. (2010). Molecular Gastronomy: A New Emerging Scienti c Discipline. Symposium A Quarterly Journal In Modern Foreign Literatures, 2313-2365. https://doi.org/10.1021/cr900105w

Blackwell, Z., \& Littlejohns, P. (2010). A Review of the Management of Dysphagia: A South African Perspective. Journal of Neuroscience Nurses, 42(2), 61-70.

Brook, S. (2015). Oral nutritional supplements: an integral part of malnutrition treatment. British Journal of Community Nursing, (July), S6-S10 1p. Retrieved from

http://ezproxy.leedsbeckett.ac.uk/login?url=http://search.ebscohost.com/login.as px?direct=true\&db=ccm\&AN=109804254\&site=eds-live \&scope=site

Cichero, J. A. Y. (2016). Adjustment of Food Textural Properties for Elderly Patients. Journal of Texture Studies, 47(4), 277-283. https://doi.org/10.1111/jtxs.12200

Cichero, J., \& Lam, P. (2014). Thickened liquids for children and adults with oropharyngeal dysphagia: The complexity of rheological considerations. Journal of Gastroenterology and Hepatology Research, Vol. 3, pp. 1073-1079. https://doi.org/10.6051/j.issn.2224-3992.2014.03.408-13

Cichero, Julie A Y. (2013). Thickening agents used for dysphagia management: effect on bioavailability of water, medication and feelings of satiety. Nutrition Journal, 12, 54. https://doi.org/10.1186/1475-2891-12-54 
Cichero, Julie A Y, Lam, P., Steele, C. M., Hanson, B., Chen, J., Dantas, R. O., ... Stanschus, S. (2016). Development of International Terminology and Definitions for Texture-Modified Foods and Thickened Fluids Used in Dysphagia Management: The IDDSI Framework. Dysphagia, 1-22. https://doi.org/10.1007/s00455-016-9758-y

Cichero, Julie A Y, Steele, C., Duivestein, J., Clavé, P., Chen, J., Kayashita, J., ... Murray, J. (2013). The Need for International Terminology and Definitions for Texture-Modified Foods and Thickened Liquids Used in Dysphagia Management: Foundations of a Global Initiative. Current Physical Medicine and Rehabilitation Reports, 1, 280-291. https://doi.org/10.1007/s40141-013-0024-z

Cole, M. (2015). Is South Africa operating in a safe and just space? In OXFAM Research Reports.

Crittenden, J. C., Trussell, R. R., Hand, D. W., Howe, K. J., \& Tchobanoglous, G. (2012). MWH's Water Treatment: Principles and Design (Third). https://doi.org/10.1038/041416a0

Detyna, J., \& Bieniek, J. (2008). Methods of statistical modeling in the process of sieve separation of heterogeneous particles. Applied Mathematical Modelling, 32(6), 992-1002. https://doi.org/10.1016/j.apm.2007.02.033

Dolatowski, Z. J., Stadnik, J., \& Stasiak, D. (2007). Applications of Ultrasound in Food Technology. Technologia Alimentaria, 6(3), 89-99.

Garcia, J., Chambers, E., Matta, Z., \& Clark, M. (2005). Viscosity Measurements of Nectar- and Honey-thick Liquids: Product, Liquid, and Time Comparisons. Dysphagia, 4(20), 325-335. https://doi.org/10.1007/s00455-005-0034-9

Garcia, J., Chambers, E., Matta, Z., \& Clark, M. (2008). Serving Temperature Viscosity Measurements of Nectar- and Honey-Thick Liquids. Dysphagia, 1(23), 65-75. https://doi.org/10.1007/s00455-007-9098-z

Garcia, J. M., Chambers IV, E., Clark, M., Helverson, J., \& Matta, Z. (2010). Quality of care issues for dysphagia: Modifications involving oral fluids. Journal of Clinical Nursing, 19(11-12), 1618-1624. https://doi.org/10.1111/j.13652702.2009.03009.x

Garin, N., De Pourcq, J. T., Martín-Venegas, R., Cardona, D., Gich, I., \& Mangues, M. 
A. (2014). Viscosity differences between thickened beverages suitable for elderly patients with dysphagia. Dysphagia, 29(4), 483-488. https://doi.org/10.1007/s00455-014-9533-x

Gunaratne, A., \& Hoover, R. (2002). Effect of heat-moisture treatment on the structure and physicochemical properties of tuber and root starches. Carbohydrate Polymers, 49(4), 425-437. https://doi.org/10.1016/S0144-8617(01)00354-X

Haghi, A. K. (2010). Advances in food science and technology. Advances in Food Science and Technology.

Hernon, P., \& Schwartz, C. (2009). Reliability and validity. Library and Information Science Research, 31(2), 73-74. https://doi.org/10.1016/j.lisr.2009.03.001

Hoebler, C., Karinthi, A., Devaux, M.-F., Guillon, F., Gallant, D. J. G., Bouchet, B., ... Barry, J.-L. (1998). Physical and chemical transformations of cereal food during oral digestion in human subjects. British Journal of Nutrition, 80, 429-436.

Hoover, R., \& Manuel, H. (1996). The Effect of Heat - Moisture Treatment on the Structure and Physicochemical Properties of Normal Maize , Waxy Maize , Dull Waxy Maize and Amylomaize V Starches. Journal of Cereal Science, 23, 153162.

Howard, M. M., Nissenson, P. M., Meeks, L., \& Rosario, E. R. (2018). Use of textured thin liquids in patients with dysphagia. American Journal of Speech-Language Pathology, 27(2), 827-835. https://doi.org/10.1044/2018_AJSLP-16-0140

Jeantet, R., Croguennec, T., Schuck, P., \& Brulé, G. (2016). Handbook of Food Science and Technology. https://doi.org/10.1002/9781119268659

Keller, H., Chambers, L., Niezgoda, H., \& Duizer, L. (2012). Issues associated with the use of modified texture foods. The Journal of Nutrition, Health \& Aging, 16(3), 195-200. https://doi.org/10.1007/s12603-011-0160-z

Keller, Heather, Chambers, L., Fergusson, D., Niezgoda, H., Parent, M., Caissie, D., \& Lemire, N. (2012). A Mix of Bulk and Ready-to-Use Modified-Texture Food: Impact on Older Adults Requiring Dysphagic Food. Canadian Journal on Aging / La Revue Canadienne Du Vieillissement, 31(03), 335-348. https://doi.org/10.1017/S0714980812000268

Kim, S., \& Joo, N. (2015). The study on development of easily chewable and 
swallowable foods for elderly. Nutrition Research and Practice, 9(4), 420-424. https://doi.org/10.4162/nrp.2015.9.4.420

Kumbár, V., \& Nedomová, Š. (2015). Viscosity and Analytical Differences between Raw Milk and UHT Milk of Czech Cows. Scientia Agriculturae Bohemica, 46(2). https://doi.org/10.1515/sab-2015-0020

Lam, P., Stanschus, S., Zaman, R., \& Cichero, J. A. (2017). The International Dysphagia Diet Standardisation Initiative (IDDSI) framework: the Kempen pilot. British Journal of Neuroscience Nursing, 13(Sup2), S18-S26. https://doi.org/10.12968/bjnn.2017.13.Sup2.S18

Landry, K. (2009). A closer look at pureed diets. Gerontology Nutrition Link: Offi Cial Newsletter of the Dietitians of Canada, Spring, 7 - 9.

Leonard, R. J., White, C., McKenzie, S., \& Belafsky, P. C. (2014). Effects of bolus rheology on aspiration in patients with dysphagia. Journal of the Academy of Nutrition and Dietetics, 114(4), 590-594. https://doi.org/10.1016/j.jand.2013.07.037

Liu, K. (2014). Molecular Recipes. Retrieved April 23, 2018, from http://www.molecularrecipes.com/culinary-foams-class/

Loret, C., Walter, M., Pineau, N., Peyron, M. A., Hartmann, C., \& Martin, N. (2011). Physical and related sensory properties of a swallowable bolus. Physiology \& Behavior, 104, 855-864.

Lotong, V., Chun, S. S., Chambers IV, E., \& Garcia, J. M. (2003). Texture and flavor characteristics of beverages containing commercial thickening agents for dysphagia diets. Journal of Food Science, 68(4), 1537-1541. https://doi.org/10.1111/j.1365-2621.2003.tb09680.x

Mayosi, B. M., Flisher, A. J., Lalloo, U. G., Sitas, F., Tollman, S. M., \& Bradshaw, D. (2009). The burden of non-communicable diseases in South Africa. The Lancet, 374(9693), 934-947. https://doi.org/10.1016/S0140-6736(09)61087-4

Mcclements, D. J. (1995). Advances in the application of ultrasound in food analysis and processing. 6(September).

McFarlane, M., Miles, A., Atwal, P., \& Parmar, P. (2014). Interdisciplinary management of dysphagia following stroke. British Journal of Neuroscience Nursing, 10(1), 13- 
20. https://doi.org/10.12968/bjnn.2014.10.1.13

McLeod, S. A. (2013). What is Validity? Retrieved August 10, 2018, from http://www.simplypsychology.org/validity.html

Mezger, T. G. (2006). The Rheology Handbook. In Hannover: Curt $R$ Vincentz Verlag. https://doi.org/10.1108/prt.2009.12938eac.006

Motoi, L., Morgenstern, M. P., Duncan, I., Wilson, A. J., \& Balita, S. (2013). Bolus moisture content of solid foods during mastication. Journal of Texture Studies, 44, 468-479.

Ney, D., Weiss, J., Kind, A., \& Robbins, J. (2009). Senescent swallowing: Impact, strategies, and interventions. Nutrition in Clinical Practice, 24(3), 395-415.

Oldewage-Theron, W. H., Dicks, E. G., \& Napier, C. E. (2006). Poverty, household food insecurity and nutrition: Coping strategies in an informal settlement in the Vaal Triangle, South Africa. Public Health, 120(9), 795-804. https://doi.org/10.1016/j.puhe.2006.02.009

Padarath, A., King, J., \& English, R. (2016). South African Health Review 2016. https://doi.org/10.1093/heapol/czq021

Pillay, M., \& Kathard, H. (2018). Renewing Our Cultural Borderlands. Topics in Language Disorders, 38(2), 143-160. https://doi.org/10.1097/TLD.0000000000000151

Roday, S. (2012). Dictionary of Food Science and Nutrition (2nd ed.; H. Bateman, H. Sargeant, \& K. McAdam, Eds.). Retrieved from https://books.google.com/books?id=2M6juAAACAAJ\&pgis=1

Salinas-Vázquez, M., Vicente, W., Brito-de la Fuente, E., Gallegos, C., Márquez, J., \& Ascanio, G. (2014). Early numerical studies on the peristaltic flow through the pharynx. Journal of Texture Studies, 45(2), 155-163. https://doi.org/10.1111/jtxs.12060

Seo, C. W., \& Yoo, B. (2013). Steady and dynamic shear rheological properties of gum-based food thickeners used for diet modification of patients with dysphagia: Effect of concentration. Dysphagia, 28(2), 205-211. https://doi.org/10.1007/s00455-012-9433-x 
Singh, S., \& Hamdy, S. (2006). Dysphagia in stroke patients. Postgraduate Medical Journal, 82(968), 383-391. https://doi.org/10.1136/pgmj.2005.043281

Statistics South Africa. (2015). Living Conditions of Households in South Africa: An analysis of household expenditure and income data using the LCS 2014/2015. In Living Conditions Survey. Retrieved from http://www.statssa.gov.za/publications/P0310/P03102014.pdf

Su, M., Zheng, G., Chen, Y., Xie, H., Han, W., Yang, Q., ... Chen, J. (2018). Clinical applications of IDDSI framework for texture recommendation for dysphagia patients. Journal of Texture Studies, 49(1), 2-10. https://doi.org/10.1111/jtxs.12306

Sun, Q., Nan, C., Dai, L., \& Xiong, L. (2015). Effect of heat-moisture treatment with maltitol on physicochemical properties of wheat starch. LWT - Food Science and Technology, 62(1), 319-324. https://doi.org/10.1016/j.Iwt.2015.01.027

Sura, L., Madhavan, A., Carnaby, G., \& Crary, M. A. (2012). Dysphagia in the elderly: management and nutritional considerations. Clinical Interventions in Ageing, 7, 287-298.

The International Dysphagia Diet Standardisation Committee. (2017). IDDSI Framework - Testing Methods. 12.

This, H. (2002). Molecular gastronomy. Angewandte Chemie - International Edition, 41(1), 83-88. https://doi.org/10.1002/1521-3773(20020104)41:1<83::AIDANIE83>3.0.CO;2-F

This, H. (2005). Modelling dishes and exploring culinary 'precisions': the two issues of molecular gastronomy. British Journal of Nutrition, 93(S1), S139. https://doi.org/10.1079/BJN20041352

This, H. (2006). Food for tomorrow? EMBO Reports, 7(11), 1-5. https://doi.org/10.1038/sj.embor.7400850

Ting, K., Liu, Y.-F., Tian-Li, G., \& Lu-Hua, Z. (2016). Relationships between Viscosity and the Contents of Macromolecular Substances from Milk with Different Storage Styles. Food Science and Technology, 4(4), 49-56. https://doi.org/10.13189/fst.2016.040401

Visagie, J. (2013). Who are the middle class in South Africa? Does it matter for policy? 
Econ3x3. Retrieved from http://www.econ3×3.org/article/who-are-middle-classsouth-africa-does-it-matter-policy

Vivanti, A. P., Campbell, K. L., Suter, M. S., Hannan-Jones, M. T., \& Hulcombe, J. A. (2009). Contribution of thickened drinks, food and enteral and parenteral fluids to fluid intake in hospitalized patients with dysphagia. Journal Human Nutrition and Dietetics, 22(2), 148-155.

World Food Program. (2017). Specialized Nutritious Foods. Retrieved July 10, 2017, from https://www.wfp.org/nutrition/special-nutritional-products

Zargaraan, A., Omaraee, Y., Rastmanesh, R., Taheri, N., Fadavi, G., Fadaei, M., \& Mohammadifar, M. A. (2013). Rheological characterization and cluster classification of Iranian commercial foods, drinks and desserts to recommend for esophageal dysphagia diets. Iranian Journal of Public Health, 42(12), 1446-1456.

Zargaraan, A., Rastmanesh, R., Fadavi, G., Zayeri, F., \& Mohammadifar, M. A. (2013). Rheological aspects of dysphagia-oriented food products: A mini review. Food Science and Human Wellness, 2(3-4), 173-178. https://doi.org/10.1016/j.fshw.2013.11.002 
Appendix A: Table: Nutritional Information of the selected SNF

\begin{tabular}{|l|l|l|}
\hline SNF Ingredients & Unit & Per 50g SNF \\
\hline Energy & $\mathrm{kj}$ & 739.5 \\
\hline Protein & $\mathrm{g}$ & 7.1 \\
\hline Glycemic Carbohydrates & $\mathrm{g}$ & 26.3 \\
\hline of which Total Sugar & $\mathrm{g}$ & 5 \\
\hline Total Fat & $\mathrm{g}$ & 3.6 \\
\hline of which Saturated Fat & $\mathrm{g}$ & 0.6 \\
\hline of which Trans Fat & $\mathrm{g}$ & $<0.008$ \\
\hline of which Monounsaturated Fat & $\mathrm{g}$ & 0.9 \\
\hline of which Polyunsaturated Fat & $\mathrm{g}$ & 2.1 \\
\hline Total Dietary Fiber \# & $\mathrm{g}$ & 5.3 \\
\hline Total Sodium & $\mathrm{mg}$ & 795 \\
\hline Vitamin A & $\mathrm{mcg}$ & 450 \\
\hline Vitamin B1 & $\mathrm{mg}$ & 0.6 \\
\hline Vitamin B2 & $\mathrm{mg}$ & 0.7 \\
\hline Vitamin B3 & $\mathrm{mg}$ & 8 \\
\hline Vitamin B6 & $\mathrm{mg}$ & 0.8 \\
\hline Folic Acid B9 & $\mathrm{mcg}$ & 200 \\
\hline Vitamin B12 & $\mathrm{mcg}$ & 1.2 \\
\hline Biotin B7 & $\mathrm{mcg}$ & 15 \\
\hline Pantothenic Acid B5 & $\mathrm{mg}$ & 2.5 \\
\hline Vitamin C & $\mathrm{mg}$ & 50 \\
\hline Vitamin D & $\mathrm{mcg}$ & 7.5 \\
\hline Vitamin E & $\mathrm{mg}$ & 7.5 \\
\hline Potassium & $\mathrm{mg}$ & 255 \\
\hline Phosphorus & $\mathrm{mg}$ & 200 \\
\hline Calcium & $\mathrm{mg}$ & 110 \\
\hline Magnesium & $\mathrm{mg}$ & 75 \\
\hline Iron & $\mathrm{mg}$ & 8.5 \\
\hline Zinc & $\mathrm{mg}$ & 6 \\
\hline Manganese & $\mathrm{mg}$ & 1.5 \\
\hline Copper & $\mathrm{mg}$ & 0.7 \\
\hline Selenium & $\mathrm{mcg}$ & 100 \\
\hline lodine & $\mathrm{mcg}$ & \\
\hline Molybdenum & & \\
\hline Chromium & & \\
\hline & & \\
\hline
\end{tabular}


Appendix B: Table: Modification Techniques for Preparing Samples

\begin{tabular}{|c|c|c|c|}
\hline $\begin{array}{c}\text { Sample } \\
\text { (Modification } \\
\text { Technique) }\end{array}$ & $\begin{array}{l}\text { Equipment } \\
\text { Required }\end{array}$ & $\begin{array}{l}\text { Ingredients } \\
\text { Required }\end{array}$ & Method \\
\hline $\begin{array}{l}\text { Baseline (standard as } \\
\text { per SNF packaging): } \\
1 \text { sample }\end{array}$ & $\begin{array}{l}\text { Bowl } \\
\text { Measuring cup } \\
\text { Measuring } \\
\text { spoon } \\
\text { Fork }\end{array}$ & $\begin{array}{l}\text { 50g SNF powder (4 } \\
\text { tablespoons) } \\
150 \mathrm{ml} \text { Water }\end{array}$ & $\begin{array}{l}4 \text { tablespoons }(50 \mathrm{~g}) \text { of SNF } \\
\text { powder added to a bowl. } \\
\text { Water added while stirring } \\
\text { with a fork. Stirred with fork } \\
\text { for } 2 \text { minutes. }\end{array}$ \\
\hline $\begin{array}{l}\text { Room Temperature } \\
\text { liquids (particle } \\
\text { separation): } 2 \\
\text { samples } \\
\text { 1. L2 RT } \mathrm{H}_{2} \mathrm{O} \\
\text { Separation } \\
\text { 2. L2 RT Milk } \\
\text { Separation }\end{array}$ & $\begin{array}{l}\text { Bowl } \\
\text { Measuring } \\
\text { spoon } \\
\text { Measuring cup } \\
\text { Fork } \\
\text { Sieve } \\
\text { Cup }\end{array}$ & $\begin{array}{l}50 \mathrm{~g} \text { SNF powder (4 } \\
\text { tablespoons) } \\
200 \mathrm{ml} \text { Cold Milk } \\
\text { AND } \\
50 \mathrm{~g} \text { SNF powder (4 } \\
\text { tablespoons) } \\
160 \mathrm{ml} \text { Cold Water }\end{array}$ & $\begin{array}{l}4 \text { tablespoons of SNF powder } \\
\text { added to a bowl. Cold water } \\
\text { (or cold milk) added while } \\
\text { stirring with the fork. Stirred } \\
\text { for at least } 2 \text { minutes. Mixture } \\
\text { strained with sieve into cup. }\end{array}$ \\
\hline $\begin{array}{l}\text { Heated liquids } \\
\text { (Separation): } 2 \\
\text { samples } \\
\text { 1. L2 Heated } \mathrm{H}_{2} \mathrm{O} \\
\text { Separation } \\
\text { 2. L2 Heated Milk } \\
\text { Separation }\end{array}$ & $\begin{array}{l}\text { Bowl } \\
\text { Measuring } \\
\text { spoon } \\
\text { Measuring cup } \\
\text { Fork } \\
\text { Sieve } \\
\text { Cup }\end{array}$ & $\begin{array}{l}\text { 50g SNF powder (4 } \\
\text { tablespoons) } \\
200 \mathrm{ml} \text { Hot Milk } \\
\text { AND } \\
50 \mathrm{~g} \text { SNF powder (4 } \\
\text { tablespoons) } \\
\text { 160ml Hot Water }\end{array}$ & $\begin{array}{l}4 \text { tablespoons of SNF powder } \\
\text { added to a bowl. Hot water } \\
\text { (or hot milk) added while } \\
\text { stirring with the fork. Stirred } \\
\text { for at least } 2 \text { minutes and } \\
\text { strained with the sieve into } \\
\text { the cup. }\end{array}$ \\
\hline $\begin{array}{l}\text { Room Temperature } \\
\text { food } \\
\text { (foaming/Aeration) } 2 \\
\text { samples } \\
\text { 1. L4 RT } \mathrm{H}_{2} \mathrm{O} \\
\text { Aeration } \\
\text { 2. L4 RT Milk } \\
\text { Aeration }\end{array}$ & $\begin{array}{l}\text { Bowl } \\
\text { Measuring } \\
\text { Spoon } \\
\text { Measuring cup } \\
\text { Hand Whisk }\end{array}$ & $\begin{array}{l}50 \mathrm{~g} \text { SNF powder (4 } \\
\text { tablespoons) } \\
100 \mathrm{ml} \text { Cold Milk } \\
\text { AND } \\
50 \mathrm{~g} \text { SNF powder (4 } \\
\text { tablespoons) } \\
80 \mathrm{ml} \text { Cold Water }\end{array}$ & $\begin{array}{l}4 \text { tablespoons of the SNF } \\
\text { powder scooped into a bowl. } \\
\text { Cold water (or cold milk) } \\
\text { added while stirring with the } \\
\text { hand whisk. Mixture whipped } \\
\text { or beat for } 2 \text { minutes until } \\
\text { light and foamy. }\end{array}$ \\
\hline $\begin{array}{l}\text { Heated food } \\
\text { (foaming/Aeration): } 2 \\
\text { samples } \\
\text { 1. L4 Heated } \mathrm{H}_{2} \mathrm{O} \\
\text { Aeration } \\
\text { 2. L4 Heated Milk } \\
\text { Aeration }\end{array}$ & $\begin{array}{l}\text { Bowl } \\
\text { Measuring } \\
\text { Spoon } \\
\text { Measuring cup } \\
\text { Hand Whisk }\end{array}$ & $\begin{array}{l}\text { 50g SNF powder (4 } \\
\text { tablespoons) } \\
100 \mathrm{ml} \text { Hot Milk } \\
\text { AND } \\
50 \mathrm{~g} \text { SNF powder (4 } \\
\text { tablespoons) } \\
80 \mathrm{ml} \text { Hot Water }\end{array}$ & $\begin{array}{l}4 \text { tablespoons of the SNF } \\
\text { powder scooped into a bowl. } \\
\text { Hot water (or hot milk) added } \\
\text { while stirring with the hand } \\
\text { whisk. Mixture whipped or } \\
\text { beat for } 2 \text { minutes until light } \\
\text { and foamy. }\end{array}$ \\
\hline
\end{tabular}


Appendix C: Table: IDDSI testing methods (The International Dysphagia Diet

Standardisation Committee, 2017)

\begin{tabular}{|c|c|}
\hline Test & Description \\
\hline Syringe Flow Test & $\begin{array}{l}\text { To test the flow rate of liquids. } \\
\text { Tools Required: } \\
\text { 10ml slip-tip syringe(s) } \\
\text { Stopwatch } \\
\text { Procedure: } \\
\text { 1. Remove the plunger from the syringe and discard } \\
\text { 2. Form a seal by blocking the nozzle of the syringe with a finger } \\
\text { 3. Fill } 10 \mathrm{ml} \text { of fluid (to the } 10 \mathrm{ml} \text { mark of the syringe) - it is suggested } \\
\text { to use another syringe to do this. } \\
\text { 4. Start the stopwatch and remove your finger from the nozzle at the } \\
\text { same time. } \\
5 \text {. Stop the liquid from flowing by replacing your finger on the nozzle at } \\
\text { 10 seconds. } \\
\text { The IDDSI framework gives detailed descriptions of the thickness of } \\
\text { liquids based on the results of the syringe flow test. }\end{array}$ \\
\hline Fork Drip Test & $\begin{array}{l}\text { Thick drinks and fluid foods can be tested by using the fork drip test. } \\
\text { Tools required: } \\
\text { Fork } \\
\text { Procedure: } \\
\text { Thick liquids and fluid foods are assessed by scooping them up with } \\
\text { the fork and observing the behaviour of the food or liquid. Observe } \\
\text { whether they flow through the slots/prongs of a fork or remains on the } \\
\text { fork. Compare against the detailed descriptions of each Level of the } \\
\text { IDDSI. }\end{array}$ \\
\hline Fork Pressure test & $\begin{array}{l}\text { For hard or firm food, the fork has been chosen as it can be used for } \\
\text { assessment of mechanical properties (hardness), in addition to } \\
\text { assessment of shape attributes such as food/bite size. As such, a Fork } \\
\text { Pressure Test is best used to assess foods in Levels } 4-7 \text { and } \\
\text { transitional foods. } \\
\text { Tools required: } \\
\text { Fork } \\
\text { Procedure: } \\
\text { A fork can be applied to the food sample to observe its behaviour when } \\
\text { pressure is applied. Pressure applied to the food sample has been } \\
\text { quantified by assessment of the pressure needed to make the thumb } \\
\text { nail blanch noticeably to white. For assessment using the Fork } \\
\text { Pressure Test, it is recommended that the fork be pressed onto the food } \\
\text { sample by placing the thumb onto the bowl of the fork (just below the } \\
\text { prongs) until blanching is observed which is estimated to be } 17 \mathrm{kPa} \text {. } \\
\text { This is the pressure of the tongue during swallowing (Steel et al., 2014). } \\
\text { Observe the behaviour of the sample and compare to the detailed } \\
\text { descriptions of the IDDSI framework. }\end{array}$ \\
\hline
\end{tabular}




\begin{tabular}{|c|c|}
\hline Spoon Tilt Test & $\begin{array}{l}\text { This test determines the stickiness of the sample (adhesiveness) and } \\
\text { the ability of the sample to hold together (cohesiveness). This test is } \\
\text { used to classify Levels } 3-5 \text {. } \\
\text { Tools required: } \\
\text { Teaspoon } \\
\text { Plate } \\
\text { Procedure: } \\
\text { Scoop a teaspoon full of the sample to be tested. Hold the spoon steady } \\
\text { over a plate, then tilt the spoon sideways in one smooth movement. } \\
\text { Observe the behaviour of the sample and compare to the detailed } \\
\text { descriptions of the IDDSI framework. }\end{array}$ \\
\hline
\end{tabular}

† L2 RT = Level 2 Room Temperature

${ }^{\ddagger}$ L4 RT = Level 4 Room Temperature

${ }^{\S}$ All measurements reported are based on the mean of three replicates 